\title{
Political Persecutions and Ideological Pressure on the Creative Intellectuals of Uzbekistan in Post-War Decades
}

\author{
Ergasheva Yu. A., Vasieva D. I., Murtazova S. B.
}

\begin{abstract}
Summary: In the article the questions of political persecutions and ideological pressure on the creative intellectuals of Uzbekistan, impact of policy of repressions of the Soviet power on cultural life of society are considered. Problems of conceptual and ideological interdependence of the repressive nature of the Soviet power and antinational orientation of the Soviet "cultural policy", the destroying impact of repressive policy on the spiritual life of people are analyzed and also the tragic fate of the representatives of the national creative intellectuals, scientists, literary figures, artists who suffered from persecutions and repressions is considered.
\end{abstract}

Keywords: political persecutions, ideological pressure, repressions, spiritual culture, science, literature, art, creative intellectuals, scientists, national culture.

\section{INTRODUCTION}

The last decade of the 20th century in all former Soviet Union was marked by large turn in life of society. The collapse of the Soviet Union and formation of the state independence of the former republics became for them a new stage of implementation of economic and social cultural changes. National independence gave a powerful impulse to development of spiritual culture of the people of Uzbekistan. Adequately to these processes there is also a restoration of historical memory, growth of interest in an old and recent history. And it is clear: many historical events of the past of the people of the republic due to the ideological, vulgar and bolshevik approaches which developed during the Soviet period were interpreted to please party bodies. Therefore freedom of a historical thought gives today the chance to approach impartially to illumination of its many pages.

\section{MAIN PART}

Recently among a number of the newspaper publications, literary and art works and scientific researches devoted to history, the subject of spiritual culture, repressions and persecutions against the national intellectuals of the period of a Stalin arbitrariness, the negative phenomena in relation to

Revised Manuscript Received on September 25, 2019

ERGAShEVA Yu. A., Professor, doctor of historical sciences, head of the department of History of Uzbekistan at Karshi Engineering and Economic Institute

VASIEVA D. I., Assoiate professor of the department "History of Uzbekistan" Karshi Engineering and Economic Institute

MURTAZOVA S. B.*, Assoiate professor of the department "History of Uzbekistan" Karshi Engineering and Economic Institute ones caused by the forceful implementation of subjective and far-fetched projects of the totalitarian power and also patriotic activities of the national intellectuals for preservation and development of national spiritual traditions takes particular interest.

In this regard it would be desirable to stop on post-war events when the next wave of repressive blow of Stalinism caused a serious loss to spiritual culture and the creative intellectuals of Uzbekistan. Persecutions and unreasonably humiliating estimates of creativity of prominent figures of national culture during the previous Soviet period could not but leave a mark on the subsequent literary and art creativity.

In a victory, which changed image of the world, the people laid huge hopes including renewal of spiritual life, but the Soviet power had its concept of management of ideology and culture in post-war years. It based on opposition of the "Soviet" culture to the West bourgeois culture which was considered as extremely dangerous to socialist thinking. According to this the creativity of the intellectuals was estimated. In the late forties and the beginning of the 50th years repressions against the best part of the national intellectuals such as writers, poets, scientists and other cultural figures of Uzbekistan were one of means of maintenance and strengthening of the authoritative power, attempt of suppression and leveling of national consciousness.

The ambiguous processes happening in society those years received direct reflection in art creativity. In fact, the ideological pressure on this sphere of human activity defined further development of literature and art up to the 90th years

As the beginning of a purposeful impact on the creative intellectuals were the resolutions of the Central Committee of the All-Union Communist Party (bolsheviks) published in 1946 «About the magazines «Zvezda» and «Leningrad», «O repertuare dramaticheskogo teatra i merakh po ego uluchsheniyu», «About the movie «Big Life» and «About the opera «Great friendship» of V. Muradelli» in 1948 and etc. These resolutions contained sharp expressions to the address of eminent persons of culture in whose works are traced "lack of principles", "political apathy", "violation of life truth", "servility before the bourgeois culture of the West", etc.

The "aiming" resolutions caused chain reaction on places: in the republican, regional, regional party organizations. The adopted local resolutions which appeared after this "main thing" looked grotesquely, so angrily and rigidly criticizing writers, poets, the editorial offices of magazines, etc., and without any accounting of

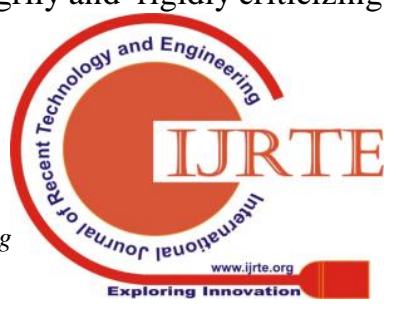


specific features of psychological, moral nature of indigenous people. Traditionally fight against dissident took place in Uzbekistan, first of all, under a banner of "eradication of nationalism". In August, 1946 the XIV plenum of the Central Committee of the Republic of Uzbekistan noted that "do not receive due repulse elements of lack of principles and political apathy in creativity of some part of writers and in the repertoire policy of theaters of the republic, the facts of withdrawal of many of them from hot topics of the present". [1]

For the organization of "due repulse" to such elements and a regulation of activity of party and state bodies of the Central Asian republics in 1947 in Tashkent was again restored Central Asian Bureau of the Central Committee of the All-Union Communist Party abolished in 1934. At its insistance in 1949-1950 the bureau and the secretariats of the Central Committee of the Communist Parties of the republics of the region subjected to severe criticism and to condemnation the activity of the Writers' Unions, artists, composers, many scientists. "Peculiar" reasons of lack of principles were found, namely the fact that " obsolete nationalist delusions and the carefree relation to mastering the Marxist-Leninist theory still seriously prevent fruitful work of «some creative specialists». Charges of "nationalism" was peculiar "feature" and a "convenient" form of implementation of Stalin repressions in the national republics. In this course was made the decision of the $\mathrm{X}$ congress of the Central Committee of Communist Party of Uzbekistan which took place in March, 1949 which called for uncompromising struggle against reactionary theories and views.

In June, 1949 the Central Committee of the Republic of Uzbekistan, having discussed work of the Writers' Union, noted that there were the elements of nationalism, national limitation, idealization of the feudal past and an obsequious worship for old feudal culture in works of the last time. The ideological order developed into a broad campaign for condemnation in scientific institutions, on pages of the press of scientists, literary critics, poets, the writers standing on the so-called "nationalist" positions which are positively estimating the historical past and national cultural values of the people.

Naturally, the Allied center in every possible way initiated "exposure" of the defects which were not existing in science, in the Uzbek literature and art. The secretary of ideology of the Central Committee of the Republic of Uzbekistan N. Mukhitdinov in the memoirs noted: «From Moscow those days there arrived the big group of workers of science and culture and together with them representatives of the Central Committee of the All-Union Communist Party (bolsheviks). They meticulously investigated works of each outstanding scientist and the cultural figure of Uzbekistan. Held a meeting of an asset where heads of group subjected to severe criticism of those who «pervert national policy» parties, «popularize archaisms», «palace poetry and music», try «to close the Uzbek culture and to tear off it from the Union». [2] In course of execution» resolutions of party on ideological questions on places many writers and figures of national culture underwent abasement, ideological defamation, removal from positions, etc. So, ideological and political charges obviously unreasonable, were put forward against the most great Uzbek writers Aybek, A. Kakhkhar, M. Sheykhzade, Shukrullo, Shukhrat, Said Ahmad, M. Ismoil and some others and also concerning the «Shark Yulduzi» and « Zvezda Vostoka» magazines.

In the late forties - the beginning of the 50th the republican press one by one placed devastating articles with charges to creative specialists. The impartial selection of these articles shows all persistent approach to the national intellectuals. So, the authors of the article "About Ideological Perversions in Works of Some Poets" V. Kostyr and K. Fayzulin with a dogmatic support on the principle of socialist realism brought various charges against poets Turab Tula, Sabir Abdullah, Kamtar Atabayev, Mirtemir, Habibi, A. Babadzhanov. Actually article answered spirit of strategy of totalitarian regime - "to keep a tight rein, "putting in fact literature and poetry in such conditions which did not contribute to their creative development at all. It is confirmed with clarity by the following estimates: "The tearful cooking of Mirtemir, like a song «Yor» got by pessimism roughly distorts the historical truth, impudently slanders our people". Or: «in the work by Turab Tula "My Uzbekistan" it is vain to look for the lines characterizing socialist Uzbekistan. The author sings landscape details existing since ancient times, sees "the shining sun", "the blossoming garden", "spring", but "finds possible not to mention a word about Stalin friendship, about life-giving Soviet patriotism. Vicious work of T. Tula is related on spirit of a cooking of bourgeois and nationalist rhymers» [3], etc. Antinational orientation of this sort of consecutive "criticism", undoubtedly, reflected the point of view and positions of single party elite.

Naturally, from their point of view only works which reflected "inspired fight of the Uzbek people for increase in a harvest of a cotton, noble feeling of love to the Communist Party, to great Stalin" enjoyed "deserved popularity".

On August 21, 1951 in the newspaper «Pravda Vostoka» was published

M. Ivanov, V. Lavrov and F. Iskanderov's articles "Away from problems of the Uzbek Soviet literature". The keynote of its contents was made by a problem of the Uzbek literary criticism. However the priorities of development of the Uzbek literary criticism allocated in it reflected significant influence of class, chauvinistic approaches. Formally as an object of criticism acted works of prominent scientists in the field of literary studies , literary criticism and philology, such as Aybek,

H. Zarifov, H. Yakubov, I.Sultanov. But actually article was directed against positive illumination and the analysis of the literary heritage of the Uzbek people. So, Aybek was accused that "incorrectly regards the compositions «Sanavbar» and «Malika and Dilorom» got by spirit of Islamic fanaticism as the national novels, H. Zarifov in transformation of the poem "Ded Corcout" into the heroic epos, and H. Yakubov for the fact that "incorrectly treats the historical phenomena", etc. [4]

Ideological execution of the creative intellectuals continued on the VI Plenum of the Writers' Union of Uzbekistan which was hastily convened in August, 1951. On it the extensive group of the national writers and poets much loved by the people underwent a rough rating. So, in speeches of official speakers it was angrily 
noted that in works by Sheykhzade "the socialist reality, images of the Soviet people are distorted; language of his works is littered with the Arab, Iranian, Turkish words, mainly religious character". The play "Alpomysh" by S. Abdullah was announced vicious as idealizing the feudal past. The poets such as T. Fattah, Zulfia, M. Babayev, X. Gulyam and others were criticized for the "endless use" of the words "roses", "nightingales", and other attributes of ancient gazelles " in some of their works, supposedly " alien to aesthetic tastes of the Soviet people ".

In other words, national writers and poets were rigidly criticized for the fact that they sought to keep national traditions, continuity of the national cultural life of people in art creativity, to preserve the memory of great spiritual heritage of the past in public consciousness.

The similar vulgar and chauvinistic criticism of any manifestations of a national originality in works of the Uzbek writers and poets made negative impact on the Uzbek literature.

Also the scientific intellectuals of the republic underwent political persecution. So, on the $\mathrm{X}$ plenum of the Central Committee of the Republic of Uzbekistan, consisting on February 21-22, 1952, scientists - historians, orientalists, literary critics who allegedly, pay not enough attention to researches of the Soviet period underwent criticism. Along with condemnation of research, scientific divisions, materials of a plenum contained also political estimates of many famous scientists. So, the philosopher V. Zakhidov was accused of idealization of activity of A. Navoi, dzhadid, the historians R. Abdushukurov, G. Rizayev, S. Radzhabov were accused of "underestimation of value of the October revolution for the people of Central Asia", A. Babakhodzhayev that "did not show a reactionary entity of a pantyurkizm", philologists A. Usmanov in promotion of "the Arab terminology alien to Uzbek", Aybek, A. Aminov, H. Zarifov, G. Karimov in "a nationalist bias". [5] Similar practice of ideological regulation and management of scientific activity caused global deformation of moral principles of scientific community.

Besides, the repressive mechanism of a totalitarian system was involved again. Process is this, amplifying more and more, developed generally in two directions: first, strengthening of brain washing of the population; secondly, direct repressive measures. Repressions against prominent representatives of the national intellectuals especially amplified in 1951-1952. Punishment of the national intellectuals, attempts of its moral and political discredit were carried out by means of a fabrication of charges of nationalism and anti-Soviet activity, arbitrary arrests, getting of the "proofs" providing the "necessary" course of judicial and extrajudicial process. As a result of the similar dramatized political charges by the beginning of 1952 for "anti-Soviet activity" Shukrullo, Maksud Sheykhzade, Shukhrat, Mirkarim Osim, Said Ahmad, Mirzakalon Ismoili, H. Suleymanov and some other writers, scientists of the republic were already sentenced to 25 years. On the $\mathrm{X}$ Plenum of the Central Committee of the Republic of Uzbekistan (February, 1952) which discussed the issue "About a State and Measures of Improvement of Ideological Work in the Republic" it was again and very vulgarly told about allegedly available serious shortcomings of works of the Uzbek writers, scientists, composers and also it was indicated the need of improvement of work on education of workers in the spirit of the Soviet patriotism and friendship of the people, fight against remnants of nationalism, feudal-bay attitudes towards the woman, etc. On the same plenum Aybek and some more writers, poets were declared nationalists. In the same month the plenum of the Writers' Union was held on which it was noted that "literary work in the Sovet state is neither a personal, nor a private affair, but state and party and public affair", and therefore from members of the Union it is required "that their works answer with the ideological and art level to inquiries of the Soviet readers and the tasks set by the Communist Party". [6] In a word, such political and ideological situation at which literature by the nature not giving in to a regulation and designed to be engaged in eternal subjects - the person, the world, morality- lost the creative, sublime lines, motives and were doomed to craftwork.

At the same time, not all fault for repressions and persecutions of the national intellectuals in the 50th years, as well as in the 30th, can be assigned only to the allied center and its policy. Unfortunately, these actions of a negative order, were carried out not only with the "help" of party and state bodies, but also some career minded representatives of the domestic intelligence.

In the memoirs N. Mukhitdinov noted that in the early fifties the first secretary of the Central Committee of the Republic of Uzbekistan A.I. Niyazov handed him the list of 60 eminent persons of culture who, allegedly, conduct "the vigorous nationalist activity which is contrary to policy of the party, periodically meet, secretly discuss problems, coordinate the estimates and conduct recruitment of supporters among the intellectuals". This list was made "by appropriate authorities together with certain employees of the creative organizations and Academy of Sciences". [7] It should be noted that by this time more than 20 people had already been convicted, many had been released from work as not credible.

The academician Mirzaali Mukhamedzhanov also remembered that at the beginning of 1952 the secretary of ideology of the Central Committee of the Republic of Uzbekistan H. Tursunov and the permanent representative of Uzbekistan in Moscow Ya. Aliyev tried "regarding exposure" to pass to the secretary of the Central Committee of the All-Union Communist Party (bolsheviks) G.M. Malenkov the list of "group of nationalists, pan-Islamists and pantyurkist" made by the management of Turk All-Union organization and the Central Committee of the republic in which were the names of nearly 150 prominent scientists, writers, cultural figures. With words: "You want to exterminate the intellectuals and to return the republic in the 37th year.?" - G.M. Malenkov drived them out of the office. [8] Whatever was the list of slandered, it was made and presented to the center not by imperial officials, but republican party and state figures and certain creative specialists from the circle of the national intellectuals.

Let's give only two examples of "diligent assistance" of such representatives of the intellectuals. So, the novel "Navoiy" by Aybek became widely known and was highly appreciated by critics, readers, party and state tops of the republic and the Union. In 1946 this novel 
was conferred the Stalin award. However in several years for this novel Aybek was accused of idealization of the feudal past and an image of Navoiy, "of an obsequious worship for old feudal culture". The wife of the writer Aybek, Z. Saidnosirova, remembered that in 1950 the accusatory letter was written (on 22 pages) against Aybek, the one was signed by a number of "colleagues- writers" - Sheverdin, Uygun, Milchakov, Oydin. They accused Aybek of nationalism. The same fate comprehended also some other his art and publicistic works. Similar charges and criticism cost Aybek many years of life. [9]

Or let's take Maksud Sheykhzade's fate. The poet Shukrullo, by the way, the victim of political repression, writes that in connection with the preparation for the $80^{\text {th }}$ anniversary of Sheykhzade, he got the official document that said : "On the basis of data on hostile anti-Soviet activity on September 21, 1952 bodies of People's Commissariat for Internal Affairs arrested Maksud Sheykhzade. In spite of the fact that Sheykhzade did not plead guilty, his nationalist, anti-Soviet activity was rather proved on the basis of evidence of Tuygun Shukurzhanov, Askad Mukhtar, Milchakov, Ramz Babadzhan and others". [10]

Speaking about those who assisted in persecution of the colleagues, we are far from attempt to shame and blacken already deceased or now healthy poets and writers. However, not a single act, whatever it may be, never remains unaswered because secret, sooner or later, becomes obvious, it is a historical axiom. Therefore justice demands to tell not only the names of those who suffered from totalitarian regime, but also those who for the wellbeing organized smear campaigns "gained" authority before the power at the expense of misfortune of the colleagues. However, for the sake of objectivity, it should be noted that later some of them realized their fault. From positions of today we can justify acts of some representatives of the intellectuals with defects of the most totalitarian system forcing to go against own conscience or to betray. Nevertheless in this regard the next lines of the wonderful poet Shukrullo are remembered:

Someone is beaten, and he is not guilty,

Someone of something in a false manner is convicted,

"So the world is arranged" - people speak.

"What can we do?" - add...

"So the world is arranged" - people speak,

But so I do not speak with them together.

I understand: the world is not guilty

That other of us forgot about honor. [11]

Violent destruction during Stalin repressions of the most prominent representatives of the creative intellectuals, talented figures of literature and art, caused an irreplaceable loss to cultural property of the Uzbek people, caused rapid destruction of its national bases. It should be noted that according to official data, in 1937-1953, in Uzbekistan only by decision of extra-judicial bodies (so-called "three") 18652 persons were repressed, from them 6038 are sentenced to execution. [12]

\section{CONCLUSION}

Defamation and repressions of the national intellectuals beat out many talented writers, poets, scientists from its ranks and had the most negative consequences in intellectual, in particular, in literary and art creativity. The emergence of weak, mediocre works, often conjuncturally brought closer to production or party topics, seriously restrained the development of national literature, national language, studying and unbiased interpretation of national history, etc. The main advantages of art creativity of any representative of the national intellectuals were estimated through a prism of principle of "socialist realism" in which the dictates were focused on ideas and political contents. However, the free creative beginning did not fit into the totalitarian system focused on conformist type of thinking. And therefore the intellectuals were considered as the serving force of this system. In case of an independent position, politically derogatory accusations were firmly imprinted on it. Nevertheless, the current active participation of the national intellectuals of Uzbekistan in strengthening of independence and revival of national and universal values, spiritual heritage of the people, demonstrates that, despite sometimes drama and severe tests in their destiny, they managed to keep the national advantage, moral potential, belief and aspirations in free and independent life. Nowadays in a new way comprehending historical events of absolutely recent years, the main thing that we have to take as a lesson from its burdensome time connected with vulgarly chauvinistic attitude of the authorities towards the creative intellectuals it is a necessity of understanding and accounting of the fact that creativity has to have an opportunity for free self-expression.

\section{LITERATURE}

1. The Communist Party of Uzbekistan in resolutions and resolutions of congresses. - Tashkent, 1968, p. 260.

2. Mukhitdinov N. the Years spent in the Kremlin. - Tashkent, 1994, p. 48.

3. East truth, on August 1951, 10.

4. East truth, on February 1952, 24.

5. The Communist Party of Uzbekistan in resolutions and resolutions of congresses. - Tashkent, 1968, p. 454.

6. TsGA RUZ, t. 2356, оп. 1, 311, 1. 18.

7. Fan va Turmush, 1993, No. 5-6, p. 9

9. Saidnosirova Z. Oybegim mening. Tashkent, 1994, p. 128.

10. Shukrullo. Qasosli dunyo. - Tashkent, 1994, p. 12.

11. Shukrullo. Your dreams: Verses and poems. - Tashkent, 1980, p. 78

12. Pravda Vostoka. May 1989, 21. 